\title{
Assessment of Entrepreneurial Traits and Intention among Undergraduate Students at Catholic University of Health and Allied sciences -Mwanza, Tanzania
}

\author{
Omary Mejjah ${ }^{1}$, Husna Ngulyavyangu ${ }^{2}$, Thandiwe Peter ${ }^{3}$, Stanley Mwita ${ }^{4 *}$ \\ ${ }^{1}$ Institute of Allied and Health Sciences \\ Catholic University of Health and Allied Sciences \\ Mwanza, Tanzania. \\ Email: sm.omary [AT] yahoo.com \\ ${ }^{2}$ School of Pharmacy \\ Catholic University of Health and Allied Sciences \\ Mwanza, Tanzania \\ Email: husnahamisi531 [AT] gmail.com \\ ${ }^{3}$ Administration department \\ Catholic University of Health and Allied Sciences \\ Mwanza, Tanzania \\ Email: thandiyvonne [AT] yahoo.com \\ ${ }^{4}$ School of Pharmacy \\ Catholic University of Health and Allied Sciences \\ Mwanza, Tanzania \\ *Email: stanleymwita [AT] gmail.com
}

\begin{abstract}
Entrepreneurship of young graduates is fundamental in mitigating the challenge of unemployment, while the role of universities is considered to be very important in developing entrepreneurial behavior. Thus, the present study aims to assess entrepreneurial traits and intention among undergraduate students at Catholic University of Health and Allied sciences -Mwanza, Tanzania. The cross-sectional descriptive study was conducted in May 2021 at Catholic University of Health and Allied Sciences. Three hundred and thirty-one (331) undergraduates were selected by stratified random sampling. Pre-tested semi-structured questionnaire was used to collect primary data. Data were fed into Microsoft excel and then exported to STATA version 14 for analysis and data were presented in frequencies, percentages and mean. The level of entrepreneurial traits of the students was moderate with overall mean of 3.6. Majority (285, 86.1\%) of students thought of themselves as capable of opening and sustaining a business to success, reflecting positive feasibility and perceived themselves as people who willingly act on their individual decisions. The major motivating factor for entrepreneurial intention indicated by the respondents was "preference for personal creativity" $(295,89.1 \%)$. However, the major perceived barrier to starting their own businesses indicated by the respondents was "lack of funds to start” $(268,90 \%)$. This study showed that there was overall moderate level of entrepreneurial traits among the undergraduate students. The findings have shown that there is high intention and that students are interested to become entrepreneurs.
\end{abstract}

Keywords--- entrepreneurship, traits, intention, undergraduate students

\section{INTRODUCTION}

Entrepreneurship is a process of integrating opportunity, resources and innovative people who are ready to take risks i.e. the entrepreneurs (Timmons \& Spinelli, 2009). Entrepreneurship plays an important role in a global economic development and is critical for sustaining economic prosperity as it creates employment, innovations, and increases the productivity growth of an economy (Kritikos, 2014; Riswanto, 2016). Previous studies have confirmed that unemployment is common among university graduates in both developed and developing countries ranging from $9.7 \%$ to $48.0 \%$ (Mok \& Jiang, 2018; Nghia, 2019; Mgaiwa, 2021). Further due to the effect of the COVID 19 pandemic, the unemployment rate still marks an increasing trend, especially among fresh graduates, Sze et al. (2021). The recent systematic review showed an association between unemployment among young people and mental health, Bartelink et al. (2020). Data from the economic crisis of 2008 showed that the increase in suicides preceded the actual rise in the unemployment rate, Nordt et al. (2015). Thus mental health systems, and the medical community in general should prepare for this challenge, particularly in this context of COVID 19 pandemic (Kawohl \& Nordt 2020). 
Globally, graduates from higher learning institutions are still facing the unemployment problem, regardless of resources such as time and money they have invested in education (Hwang, 2017). Entrepreneurship of young graduates is fundamental in mitigating the unemployment problem, while the role of universities is considered to be very important in developing entrepreneurial behavior (Silva \& Nobre , 2018).

Personality traits play a vital role in determining behavior of an individual (Tran \& Von Korflesch, 2016). Literature provides support for personality traits being associated with entrepreneurship such as intention to start a venture (Khan \&Ahmed, 2011; Şahin et al, 2019). Thus, the present study aims to assess entrepreneurial traits and intention among undergraduate students at Catholic University of Health and Allied sciences -Mwanza, Tanzania.

\section{LITERATURE REVIEW}

\subsection{Entrepreneurship}

According to Raposo \& Paco (2011) entrepreneurship is a vigorous process of vision and creation of new business enterprises by individuals or small groups that requires energy, passion and creativity. Cadar \& Badulescu (2015) defined entrepreneurship as an ability to initiate, innovate, take decisions, and being responsible enough to take risks of undertaking economic activities by an individual who possesses a certain capital. Entrepreneurship is a term that refers to an individual who takes the risk of turning a vision into a successful business enterprise (Jwara \&Hoque , 2018). Further, Hessels \& Naude (2017) defined entrepreneurship as the resource, process and state of being through which individuals with ability and agency utilize positive opportunities in the market for generating individual and/or social value. Onu (2013) described entrepreneurship as a process where individuals use their talents, efforts, and resources to establish their own ventures that capitalize on business opportunities and create value.

\subsection{Entrepreneurial Traits}

Entrepreneurial activities are risky endeavors by nature, risk describes a preference to uncertainty with a distribution of chances over certainty, Zhang et al (2015). According to (Douglas \& Shepherd , 2002) positive attitude toward risk or a willingness to bear uncertain results is an important trait of an entrepreneur. Another important trait of an entrepreneur is locus of control, which is the ability perceived by an individual to control events in his/her life Farradinna et al., (2019). It can be internal or external in nature. People who have internal locus of control believe that they are able to control everything in their lives, whereas people with external locus of control believe that there is an external power controlling their life (Çolakoğlu \& Gözükara, 2016). The study conducted by Khanka (2009) reported a higher performance in entrepreneurs who had an internal locus of control compared to those who had an external locus of control. Further, entrepreneurs' ability to be successful is dependent on their resilience and ability to be innovative (Ngah \& Salleh, 2015). An innovation is the implementation of new ideas or creating new products or processes different from existing ones, Gault (2018). The Innovative trait is regarded as a part of strategic orientation of making new ideas a reality, resulting in creative ideas and thereby introduces innovative events, sense opportunities for new products, or a way of problem solving and implementing it (O’Regan \& Ghobadian, 2005). Furthermore, (Douglas \& Fitzsimmons, 2005), reported that promising entrepreneurs are motivated with the desire to be their own boss. Desire for independence is one of the main features of entrepreneur traits, it enables an individual to make plans for the future and take all the decisions himself, Joseph (2017). According to Lee et al., (2005), individuals possessing high desire for independence have better chances to be an entrepreneur. In addition to personality traits, several demographic factors affecting entrepreneurship are age, sex, education, work experience and role models (Ambad \& Damit., 2016).

\subsection{Entrepreneurial Intention}

Entrepreneurial intent refers to the intention of starting a new business, (Engle et al., 2010). The intention is an intellectual state, or state of mind, in which people become motivated to focus on a particular goal (Chhabra et al., 2020). The study conducted by Miralles et al., (2016) revealed that a successful business enterprise formation depends on the intention. The intention is a contributing factor in initiating venture formation and has substantial impact on entrepreneurial competence (Joensuu-Salo et al., 2021). The entrepreneurial intention is mainly dependant on three factors, namely, propensity to act, perceived desirability and perceived feasibility (Dissanayake., 2013; Cardoso et al., 2018).

Propensity to act is defined as how people are enthusiastic to explore and carry out entrepreneurial opportunities, without a significant propensity to act, it is difficult to attain well-formed intentions, Krueger (1993). The propensity to act is closely related to the locus of control and is closely linked with initiating and maintaining goal-directed behaviours , as it reflects the volitional components of intentions (Krueger et al., 2000). The propensity to act is reflected in the volitional (power of making choices) aspects of entrepreneurs' behaviour (Moghavvemi et al., 2016). Entrepreneurial intentions are determined by the perception of what the individual finds desirable (Krueger \& Brazeal., 1994). According to Achchuthan \& Nimalathasan, (2012) entrepreneurial motivation is significantly determined by the desirability for self-employment. Perceived desirability is the strong determinant of behavioural intention and entrepreneurs with a robust perception of 
desirability (i.e., the system is appealing) may form the intention to act even when they perceive themselves as having insufficient skills and poor knowledge, a higher level of perceived desirability may lead to higher levels of propensity to act (Devonish et al., 2010; Fitzsimmons \& Douglas., 2011). According previous studies, perceived feasibility significantly affect behavioural intention to take action, as perceived feasibility is more than "I can do this", where it also includes "I can figure out how to do this", perceived behavioral control (and I will keep trying in the face of adversity) (Krueger., 1998; Shook \& Bratianu ., 2008).

\section{METHODOLOGY}

\subsection{Study Area and Design}

The cross-sectional descriptive study was conducted in May 2021 at Catholic University of Health and Allied Sciences (CUHAS) which is located at Bugando Hill, within the Bugando Medical Centre (BMC) premises in Nyamagana district, Mwanza -Tanzania. The University is involved in training, research and consultancy services. The University offers the following medical and health related undergraduate programmes; Doctor of Medicine (MD), Bachelor of Science in Nursing (BSc.N), Bachelor of Pharmacy (B.Pharm), Bachelor of Medical Laboratory Science (BMLS), Bachelor of Science in Medical Imaging and Radiotherapy (BSc.MIR). The University also provides entrepreneurship education to equip all students with entrepreneurial skills. The study included all undergraduate students. Ethical clearance for the study was obtained from the joint CUHAS/BMC research ethics and review committee.

\subsection{Sample Size and Sampling Procedure}

Sample size was calculated by using Taro Yamane formula for cross sectional studies

Whereby,

$$
n=\frac{N}{1+N(e) 2}
$$

$\mathrm{n}=$ sample size,

$\mathrm{N}=$ population size 1908 , and

$\mathrm{e}=$ level of precision which is $5 \%(0.05)$

$$
\begin{gathered}
n=\frac{1908}{1+1908(0.05) 2} \\
n=331
\end{gathered}
$$

Therefore, minimum sample size was 331

Sampling procedure was stratified random sampling. Sample of students in each class were as follows; MD-190 students, BSc.N- 60 students, B. Pharm-42 students, BMLS- 32 students and BSc.MIR-7 students.

\subsection{Data Collection Procedure and Tools}

A set of pretested semi-structured questionnaire was employed to collect primary data. The tool comprised of questions which extracted information on demographic information including age, gender, course, year of study, self-employment of parent, entrepreneurial education and any business experience. Also, dimensions regarding entrepreneurial traits such as tendency to take risks, internal control, innovativeness and desire for independence. The level of entrepreneurial traits was measured on a five-point Likert-type scale with alternative responses of very low (1), low (2), moderate (3), high (4) and very high (5). Entrepreneurial intention was measured using don't know/yes/no responses. Lastly, the factors influencing entrepreneurial intention were listed to identify those that may motivate students for entrepreneurial intention and those perceived as barriers. This method was adopted from the study conducted by Afolabi et al., (2016).

\subsection{Data Analysis}

Data were fed into Microsoft excel and then exported to STATA version 14 for analysis and data were presented in frequencies, percentages and mean.

\section{RESULTS}

The demographic distribution of the Students is shown in Table 1. Most of the students were 21-23 years old (165, 49.9\%). Out of the 331, Male were 167 (50.5\%). Majority (190,57.4\%) of the students were MD, their parents were self-employed $(191,57.7 \%)$ and have business experience $(194,58.6 \%)$. Almost half $(174,52.6 \%)$ of the students claimed to have entrepreneurial education. 
Table 1: Demographic distribution of undergraduate students

\begin{tabular}{|l|l|l|l|}
\hline Variable & Distribution & Frequency & Percent \\
\hline Age & $18-20$ years & 21 & 6.3 \\
& $21-23$ years & 165 & 49.9 \\
& $24-26$ years & 115 & 34.7 \\
& 27 and above & 30 & 9.1 \\
\hline Gender & Male & 167 & 50.5 \\
& Female & 164 & 49.5 \\
\hline *Course & BSc. MIR & 7 & 2.1 \\
& BMLS & 32 & 9.7 \\
& B.Pharm & 42 & 12.7 \\
& BSc.N & 60 & 18.1 \\
& MD & 190 & 57.4 \\
\hline Self-employment of parent & No & 140 & 42.3 \\
& Yes & 191 & 57.7 \\
\hline Entrepreneurship education & No & 157 & 47.4 \\
& Yes & 174 & 52.6 \\
\hline Any business experience & No & 137 & 41.4 \\
& Yes & 194 & 58.6 \\
\hline
\end{tabular}

* Bachelor of Science in Medical Imaging and Radiotherapy (BSc. MIR), Bachelor of Medical Laboratory Science (BMLS), Bachelor of Pharmacy (B.Pharm), Bachelor of Science in Nursing (BSc.N),

Doctor of Medicine (MD).

Table 2 present responses of the students' entrepreneurial intention. Most of students $(262,79.1 \%)$ felt interested to have their own business, reflecting positive desirability. Majority $(285,86.1 \%)$ of students thought of themselves as capable of opening and sustaining businesses to success, reflecting positive feasibility. Likewise, regarding the propensity of the students to act on business opportunities, $285(86.1 \%)$ perceived themselves as people who willingly act on their individual decisions.

Table 2. Entrepreneurial intention of Students after their graduation

\begin{tabular}{|l|l|l|l|l|}
\hline Measured variable & Item & \multicolumn{3}{|c|}{ Responses f (\%) } \\
\cline { 3 - 5 } & & I don't know & No & Yes \\
\hline $\begin{array}{l}\text { Perceived } \\
\text { desirability }\end{array}$ & Attraction to have own business & $44(13.3)$ & $25(7.6)$ & $262(79.1)$ \\
\hline $\begin{array}{l}\text { Perceived } \\
\text { feasibility }\end{array}$ & $\begin{array}{l}\text { Thought of self as capable of } \\
\text { successfully starting and nurturing a } \\
\text { business to success }\end{array}$ & $28(8.5)$ & $18(5.4)$ & $285(86.1)$ \\
\hline Propensity to act & $\begin{array}{l}\text { Seeing self as someone that readily } \\
\text { acts on personal decisions }\end{array}$ & $19(5.7)$ & $27(8.2)$ & $285(86.1)$ \\
\hline
\end{tabular}

Determination of the level of entrepreneurial traits of the students shown in Table 3 whereby "desire for independence" scored higher mean (4.1) and the mean scores for other moderate: "locus of control" (3.8), "risk taking" (3.3), and "innovation" (3.1). Overall mean level of entrepreneurial was 3.6.

Table 3. Level of entrepreneurial traits of the Students

\begin{tabular}{|l|l|}
\hline Variable & Mean \\
\hline Risk taking & 3.3 (moderate) \\
\hline Locus of control & 3.8 (moderate) \\
\hline Innovation & 3.1 (moderate) \\
\hline Desire for independence & 4.1 (high) \\
\hline TOTAL & 14.3 \\
\hline OVERALL AVERAGE & 3.6 (moderate) \\
\hline
\end{tabular}


Table 4 represents motivating factors and barriers for students' entrepreneurial intention. The major motivating factor for entrepreneurial intention indicated by the respondents was "preference for personal creativity" (295, 89.1\%). Other factors were "desire for independence and being own boss" $(288,87 \%)$, "willingness to accept risks and challenges involved in a business" (282, 85.2\%), and "financial rewards' $(278,84 \%)$. Further, the major perceived barrier to starting their own businesses indicated by the respondents was "lack of funds to start" $(268,90 \%)$. Others were "uncertain financial returns" (227, 68.6\%), "Unwilling to take risk" (196, 59.2\%), "indecision as to business of interest" (146, 44.1\%), "lack of entrepreneurs in the family" $(74,22.4 \%)$, "age" $(49,14.8 \%)$ and "gender" $(36,10.9 \%)$.

Table 4. Motivating factors and barriers for students' entrepreneurial intention

\begin{tabular}{|l|l|l|}
\hline $\begin{array}{l}\text { Perceived factors influencing } \\
\text { decision to start } \\
\text { business }\end{array}$ & $\begin{array}{l}\text { Number that selected factor } \\
\text { out of total respondents }\end{array}$ & $\begin{array}{l}\text { Percent } \\
(\%)\end{array}$ \\
\hline Perceived motivating factors & \multicolumn{2}{|l|}{} \\
\hline $\begin{array}{l}\text { Desire for independence and being } \\
\text { own boss }\end{array}$ & 288 & 87.0 \\
\hline Preference for personal creativity & 295 & 89.1 \\
\hline Financial reward and & 278 & 84.0 \\
\hline $\begin{array}{l}\text { Willingness to accept risks and } \\
\text { challenges involved }\end{array}$ & 282 & 85.2 \\
\hline $\begin{array}{l}\text { Perceived barriers } \\
\text { Unwilling to take risk }\end{array}$ & 196 & 59.2 \\
\hline Uncertain financial returns & 227 & 68.9 \\
\hline Lack of funds to start a business & 268 & 90.0 \\
\hline Indecision as to business of interest & 146 & 44.1 \\
\hline Lack of entrepreneurs in a family & 74 & 22.4 \\
\hline Age & 49 & 14.8 \\
\hline Gender & 36 & \multicolumn{2}{|l|}{} \\
\hline
\end{tabular}

\section{DISCUSSION}

The study has examined undergraduate students' intention to pursue entrepreneurship and their levels of entrepreneurial traits. Further, we investigated motivators and barriers to intentions. The findings have shown there is high intention; that students are interested to become entrepreneurs, as more than three quarters of respondents were attracted to have own business, thought themselves as capable of successfully starting and nurturing a business to success and perceived themselves as people who willingly act on their individual decisions. The main entrepreneurial trait was desire for independence. Majority of students were motivated by preference for personal creativity while the main barrier for intention to pursue entrepreneurship was lack of funds to start a business.

According to Shapero's model of entrepreneurial event, it considers starting a business as the result of the interaction among contextual factors, which would act through their influences on the individual's perceptions. Shapero listed three dimensions that decide entrepreneurial intention, namely "Perceived desirability," "Perceived feasibility," and "Propensity to act (Nguyen, C., 2017). Our findings that the students had high scores on items measuring entrepreneurial intention are in line with a previous study conducted in Nigeria which showed that majority of students felt interested to have their own businesses (perceived desirability) and had high levels of perceived feasibility and propensity to act (Afolabi et al., 2016). When students possess proactive personality and are optimistic about their own abilities and skills and likelihood to control the process of creating and sustaining a business, their entrepreneurial intentions increase (Adu et al., 2020). A proactive personality enhances an individual's propensity to act. This personality can be enhanced by entrepreneurial education. People with high proactive personalities are more likely to: believe that they can do, be resilient to strive, create something new, exploit opportunities and deal with risk (Fuller et al., 2018). 
The personality traits had a positive effect on the entrepreneurial intention. Students in the current study were reported to have the following entrepreneurial traits: willingness to take risks, locus of control, innovation and desire for independence. Previous studies reported the need of the following extra traits in order to succeed in entrepreneurship: creativity, problem solving, perseverance, passion and need for achievement (Afolabi et al., 2016). Moreover, students with entrepreneurial intentions were reported in other studies to be more in control of the situations in their lives, highly achievement motivated and had more tolerance when exposed to any unpleasant or unfavorable situation (Anwar \& Saleem., 2019). Notably, big five personality traits (openness, conscientiousness, extraversion, agreeableness, emotional stability) are most powerful when predicting entrepreneurship intentions and success (Bergner S., 2020).

In agreement with previous studies, undergraduate students in the current study with entrepreneurial intention are motivated by factors such as preference for personal creativity, desire for independence and being own boss (Benz \& Frey., 2008; Afolabi et al., 2016). Further, another study reported extrinsic rewards and change management inspire students to start up a new business whilst government support plays a significant role in promoting entrepreneurship (Ooi \& Ahmad., 2012). The intention to become entrepreneurs goes with an anticipation of obstacles and barriers. Consistency with other studies, main barriers reported in this study were lack of funds to start a business and uncertainty in financial returns (Ooi \& Ahmad., 2012; Afolabi et al., 2016). It is worth to note that, when students believe that the success or failure of starting and sustaining a business is largely due to chance and not factors within their control it is likely to discourage them to want to own a business (Adu et al., 2020).

The current study has some limitations. First, this study was conducted in a single university which may restrict its generalizability to other research settings. Second, administering of the questionnaires might cause weakness to the results: respondents are likely to have responded without giving their answer much thought thus leading to information bias. We recommend that further studies to explore entrepreneurial traits and intention among undergraduate students of other medical and non-medical universities in Tanzania. Moreover, future studies should focus on graduates who develop their careers as entrepreneurs.

\section{CONCLUSION}

Entrepreneurship gives students a different way of looking at the world, particularly when choosing to develop their own businesses and being own boss after graduation. The study has examined CUHAS undergraduate students' intention to pursue entrepreneurship, their entrepreneurial traits, motivators of intention, and obstacles to intentions. This study showed that there was overall moderate level of entrepreneurial traits among the undergraduate students. The findings have shown that there is high intention and that students are interested to become entrepreneurs. Students are motivated by factors such as preference for personal creativity, desire for independence and being own boss. However, main barriers reported in this study were lack of funds to start a business and uncertainty in financial returns.

\section{REFERENCES}

Achchuthan , S., Nimalathasan, B. (2012) 'Entrepreneurial motivation and selfemployment intention: case study on management undergraduates of university of Jaffna. In C.N. Wickramasinghe \& W.M. madururupperuma (Eds), Serious in Management Business( Economics and Entrepreneurship). University of Kell'.

Adu, I.N., Boakye, K.O., Suleman, A.-R., Bingab, B.B.B. (2020) 'Exploring the factors that mediate the relationship between entrepreneurial education and entrepreneurial intentions among undergraduate students in Ghana. Asia Pacific Journal of Innovation and Entrepreneurship, 14 (2), 215-28. https://doi.org/10.1108/APJIE-07-2019-0052'.

Afolabi, M. O., Ola-Olorun, O. J., Abereijo, I. O.,Uchegbu, V. I. (2016) 'Assessment of Entrepreneurial Traits and Intention of Pharmacy Students in Obafemi Awolowo University, Ile-Ife, Nigeria. Journal of Pharmaceutical Research International, 10(2), 1-11. doi: 10.9734/BJPR/2016/22855.'

Ambad, S.N.A, Damit, D.H.D. (2016) 'Determinants of Entrepreneurial Intention Among Undergraduate Students in Malaysia. Procedia Economics and Finance, 37, 108-114'.

Anwar, I., Saleem, I. (2019) 'Exploring entrepreneurial characteristics among university students: an evidence from India. Asia Pacific Journal of Innovation and Entrepreneurship, 13 (3), 282-95. https://doi.org/10.1108/APJIE-07-2018-0044'.

Bartelink VHM, Zay Ya K, Guldbrandsson K, Bremberg S (2020) 'Unemployment among young people and mental health: A systematic review. Scand J Public Health, 48(5),544-58. doi: 10.1177/1403494819852847’.

Benz, M., Frey, B. (2008) 'Being independent is a great thing: Subjective evaluations of selfemployment and hierarchy. Economica, 75(298),362-83.'

Bergner S. (2020) 'Being Smart Is Not Enough: Personality Traits and Vocational Interests Incrementally Predict Intention, Status and Success of Leaders and Entrepreneurs Beyond Cognitive Ability. Front Psychol, 11,204. doi: 10.3389/fpsyg.2020.00204'. 
Cadar, O., Badulescu, D. (2015) 'Entrepreneur, Entrepreneurship and Intrapreneurship. A Literature Review. Munich Personal RePEc Archive Paper Series, Paper No. 78871'.

Cardoso, A.,Cairrão, A.,Petrova,D., Jorge,F. (2018) 'Assessment of the Effectiveness of the Entrepreneurship Classes in the Bulgarian Secondary Education. Journal of Entrepreneurship Education, 21(2), 1-21'.

Chhabra, S., Raghunathan, R., Rao, N.V.M. (2020) “"The antecedents of entrepreneurial intention among women entrepreneurs in India”, Asia Pacific Journal of Innovation and Entrepreneurship, 14 (1), 76-92.'

Çolakoğlu, N., Gözükara, I. (2016) 'A Comparison Study on Personality Traits Based on the Attitudes of University Students toward Entrepreneurship. Procedia - Social and Behavioral Sciences, 229, 133-40. https://doi.org/10.1016/j.sbspro.2016.07.122'.

Devonish, D., Alleyne, P., Charles-Soverall,W., Marshall, A.Y., Pounder, P. (2010) 'Explaining entrepreneurial intentions in the Caribbean. International Journal of Entrepreneurial Behavior \& Research, 16 (2), 149-71.'

Dissanayake, D.M.N.S.W., (2013) 'The Impact of Perceived Desirability and Perceived Feasibility on Entrepreneurial Intention among Undergraduate Students in Sri Lanka: An Extended Model. The Kelaniya Journal of Management, 2(1), 39-57'.

Douglas, E., Shepherd, D. (2002) 'Self-Employment as a Career Choice: Attitudes, Entrepreneurial Intentions, and Utility Maximization.’'Entrepreneurship Theory and Practice.,26(3),81-90.'

Douglas, E.J., Fitzsimmons, J.R. (2005) 'Entrepreneurial Intentions towards Individual vs. Corporate Entrepreneurship. SEAANZ 2005 Conference, Armidale, NSW, September 2005, 25-30.'

Engle, L. R., Dimitriadi, N., Gavidia, J. V., Schlaegel, C., Delanoe, S., Alvarado, I., et al. (2010) 'Entrepreneurial intent: A twelve-country evaluation of Ajzen's model of planned behavior. International Journal of Entrepreneurial Behaviour \& Research , 16 (1),35 - 57.'

Farradinna, S., Fadhlia, T.N, Azmansyah.D. (2019) 'Psychological Resilience Predicted by Personality Traits, Locus of Control and Self-Regulation of Young Entrepreneurs in Pekanbaru. Global J. Bus. Soc. Sci. Review, 7(1), 1'.

Fitzsimmons, J.R., Douglas, E.J. (2011) 'Interaction between feasibility and desirability in the formation of entrepreneurial intentions. Journal of Business Venturing, 26 (4), 431-40.’

Fuller, B., Liu, Y., Bajaba, S., Marler, L.E., Prat, J. (2018) 'Examining how the personality, selfefficacy, and anticipatory cognitions of potential entrepreneurs shape their entrepreneurial intentions. Personality and Individual Differences, 125(5), 120-5.'

Gault, F. (2018) 'Defining and measuring innovation in all sectors of the economy. Research Policy, 43 (3), 617-22. 10.1016/j.respol.2018.01.007'.

Hessels, J., Naude, W. (2017) 'The Intersection of the Fields of Entrepreneurship and Development Economics: A Review towards a New View. Discussion paper series, Paper No.11103, IZA Institute of Labour Economics, Bonn, Germany.'

Hwang, Y. (2017) 'What Is the Cause of Graduates' Unemployment? Focus on Individual Concerns and Perspectives. Journal of Educational Issues, 3(2), 1-10. http://dx.doi.org/ 10.5296/jei.v3i2.11378.'

Joensuu-Salo S, Viljamaa A, Varamäki E. (2021) 'Understanding Business Takeover Intentions-The Role of Theory of Planned Behavior and Entrepreneurship Competence. Administrative Sciences, $11(3)$, 61. https://doi.org/10.3390/admsci11030061'.

Joseph,I. (2017) 'Factors Influencing International Student Entrepreneurial Intention in Malaysia. American Journal of Industrial and Business Management, 7, 424-8. doi: 10.4236/ajibm.2017.74030.'

Jwara, N., Hoque, M. (2018) 'Entrepreneurial Intentions among University Students: A Case Study of Durban University of Technology. Academy of Entrepreneurship Journal, 24.'

Kawohl, W., \& Nordt, C. (2020) 'COVID-19, unemployment, and suicide. The lancet. Psychiatry, 7(5), 389-90. https://doi.org/10.1016/S2215-0366(20)30141-3’.

Khan, M., Ahmed, I. (2011) 'Impact of personality traits on entrepreneurial intentions of university students. Interdisciplinary Journal of Research in $\quad$ Business, 1 (4), http://joc.hcc.edu.pk/faculty_publications/jochcc2009_1.pdf'.

Khanka, S. (2009) 'Motivational orientation of Assamese entrepreneurs in the SME sector. The Journal of Entrepreneurship, 18 (2), 209-18.'

Kritikos, A. S (2014) 'Entrepreneurs and their impact on jobs and economic growth. IZA World of Labor.' 
Krueger, N. (1993) 'The impact of prior entrepreneurial exposure on perceptions of new venture feasibility and desirability. Entrepreneurship Theory and Practice Journal, 5 (3), 315-30.'

Krueger, N., Brazeal, D.V. (1994) 'Entrepreneurial potential and potential entrepreneurs. Entrepreneurship Theory and Practice Journal, 18 (3), 91-104.'

Krueger, N., Reilly, M.D., Carsrud, A.L. (2000) 'Competing models of entrepreneurial intention. Journal of Business Venturing, 15 (6), 411-32.'

Krueger, N.J. (1998) 'Encouraging the identification of environmental opportunities. Journal of Organizational Change Management, 11 (2), 174-83.'

Lee, L., Wong, P., Ho, Y. (2005) 'Entrepreneurship Propensities: The Influence of Self-Efficacy, Opportunity Perception, and Social Networks. doi. 10.2139/ssrn.856265'.

Mgaiwa, S. J (2021) 'Fostering Graduate Employability: Rethinking Tanzania's University Practices. SAGE Open. doi:10.1177/21582440211006709'.

Miralles, F., Giones, F., Riverola, C. (2016) "'Evaluating the impact of prior experience in entrepreneurial intention", International Entrepreneurship and Management Journal, Vol. 12 No. 3, pp. 791-813.'

Moghavvemi, S., Mohd Salleh, N.A., Standing, C. (2016) 'Entrepreneurs adoption of information system innovation: The impact of individual perception and exogenous factors on entrepreneurs behavior. Internet Research, 26 (5), 1181 -208.'

Mok, K. H., Jiang, J (2018) 'Massification of higher education and challenges for graduate employment and social mobility: East Asian experiences and sociological reflections. International Journal of Educational Development, 63, 44-51.'

Ngah, R., Salleh, Z. (2015) 'Emotional Intelligence and Entrepreneurs' innovativeness towards Entrepreneurial Success: A Preliminary Study. American Journal of Economics, 5 (2), 2015, 285-90. doi: 10.5923/c.economics.201501.37.'

Nghia, T.H (2019) 'Building soft skills for employability: Challenges and practices in Vietnam. Routledge.'

Nguyen, C. (2017) 'Entrepreneurial intention of international business students in Vietnam: a survey of the country joining the Trans-Pacific Partnership. J Innov Entrep, 6, 7. https://doi.org/10.1186/s13731-017-0066-Z’.

Nordt C, Warnke I, Seifritz E, Kawohl W. (2015) 'Modelling suicide and unemployment: a longitudinal analysis covering 63 countries, 2000-11. Lancet Psychiatry, 2, 239-45.'

Onu, A.J.C. (2013) 'Stimulating entrepreneurship in educational institutions in Nigeria. European scientific journal, 9(25), 38-46.'

Ooi, Y.K, Ahmad, S. (2012) 'A study among university students in business start-ups in Malaysia: Motivations and obstacles to become entrepreneurs. International Journal of Business and Social Science (IJBSS), 3 (19), 181-92'.

O’Regan N., Ghobadian A. (2005) 'Innovation in SMEs: the impact of strategic orientation and environmental perceptions. International Journal of Productivity and Performance Management, 54 (2), 81-97.'

Raposo, M., Paco, A. (2011) 'Entrepreneurship education: Relationship between education and entrepreneurial activity, Psicothema, 23(3), 453-7.'

Riswanto, A. (2016) 'The Role of the Entrepreneur in Innovation and in Economic Development. In 2016 Global Conference on Business, Management and Entrepreneurship. Atlantis Press'.

Şahin, F., Karadağ, H., Tuncer, B. (2019) 'Big five personality traits, entrepreneurial self-efficacy and entrepreneurial intention: A configurational approach. International Journal of Entrepreneurial Behavior \& Research, 25 (6), $1188-211$. https://doi.org/10.1108/IJEBR-07-2018-0466'.

Shook, C.L., Bratianu, C. (2008) 'Entrepreneurial intent in a transitional economy: an application of the theory of planned behavior to Romanian students. International Entrepreneurship Management Journal, 6 (3), 231-47.'

Silva, A. \& Nobre, N. (2018) 'Students’ Entrepreneurial Propensity: An Exploratory Study from a Portuguese Polytechnic School. Journal of Entrepreneurship and Organization Management, 7(1), 1-6.'

Sze, C.C and Ai, Y. J., Fern, Y. S., \& Jomay, Y (2021) 'Entrepreneurial Intention Among the University Students: Personality Traits that Matter. International Journal of Entrepreneurship, Business and Creative Economy, 1(1), 1-12. https://doi.org/10.31098/ijebce.v1i1.425'.

Timmons, J. A., \& Spinelli, S. (2009) 'New Venture Creation: Entrepreneurship for the 21st Century. 8th edition: McGrawHill.' 
Tran, A.T.P., Von Korflesch, H. (2016) 'A conceptual model of social entrepreneurial intention based on the social cognitive career theory. Asia Pacific Journal of Innovation and Entrepreneurship, 10 (1); 17-38. https://doi.org/10.1108/APJIE-12-2016-007'.

Zhang, P., Wang, D., Owen, C. (2015) 'A Study of Entrepreneurial Intention of University Students. Entrepreneurship Research Journal, 5 (1), 61-82. https://doi.org/10.1515/erj-2014-0004’. 